\title{
A new Trichoncoides Denis, 1950 (Aranei: Linyphiidae) from a semi-desert in the Caspian Lowland
}

\section{Новый вид рода Trichoncoides Denis, 1950 (Aranei: Linyphiidae) из полупустыни Прикаспийской низменности}

\author{
Andrei V. Tanasevitch* \& Tatyana V. Piterkina \\ А.В. Танасевич*, Т.В. Питеркина**

\begin{abstract}
* Centre for Forest Ecology and Production, Russian Academy of Sciences, Profsoyuznaya Str., 84/32, Moscow 117997, Russia. E-mail: and-tan@mail.ru

* Центр по проблемам экологии и продуктивности лесов РАН, Профсоюзная ул. 84/32, Москва 117997, Россия.

** Institute of Ecology and Evolution, Russian Academy of Sciences, Leninsky Prospect, 33, Moscow 119071, Russia. E-mail: piterkina@yandex.ru

** Институт проблем экологии и эволюции РАН, Ленинский проспект, 33, Москва 119071, Россия.
\end{abstract}

KEY WORDS: Spiders, Linyphiidae, new species, semi-desert, steppe.

КЛЮЧЕВЫЕ СЛОВА: Пауки, Linyphiidae, новый вид, полупустыни, степи.

ABSTRACT. A new linyphiid species of the genus Trichoncoides is described from a clayey semi-desert in the environs of both Dzhanybek, western Kazakhstan and Lake Elton, Volgograd Area, southern Russia. The new species is similar to T. piscator (Simon, 1884), but differs well by the peculiar shape of the palpal tibia, of the anterior radical process in the male, as well as by the details of epigyne and vulva structure in the female.

РЕЗЮМЕ. Из глинистой полупустыни в окрестностях пос. Джаныбек, Западный Казахстан и оз. Эльтон, Волгоградская обл., юг России описан новый вид пауков-линифиид из рода Trichoncoides. Вид близок к T. piscator (Simon, 1884), но хорошо отличается главным образом деталями строения голени пальпы самца, а также эпигины и эндогины самки.

\section{Introduction}

The Caspian Lowland covers a huge, mostly desert to semi-desert or steppe area lying northwest, north and northeast of the Caspian Sea within both Russia and western Kazakhstan [Milkov \& Gvozdetsky, 1986]. It is from that region that 13 new linyphiid taxa (11 species and two genera) have recently been described [Tanasevitch, 1986, 1987, 1993, 2004; Tanasevitch \& Piterkina, 2007; Gnelitsa, 2008; Gnelitsa \& Ponomarev, 2010], suggesting a rich and peculiar spider fauna. This statement is further documented due to the discovery of a still one more new linyphiid found both in southern Russia and western Kazakhstan.

\section{Region, Material and Methods}

The paper is based on the spider material collected in 2004-2007 and 2011 in the environs of the Dzhany- bek Research Station of the Institute of Forestry, Russian Academy of Sciences, Western Kazakhstan Area, Kazakhstan, as well as in the environs of Lake Elton, Volgograd Area, Russia.

The study area occupies a flat plain in the northwestern Caspian Lowland, much of which supports the semi-desert belt [Milkov \& Gvozdetsky, 1986]. This is the most arid territory of the Ciscaspian semi-desert because of increased salinity and the absence of internal drainage. The area is characterized by a complex pattern of the soil and vegetation covers and is composed of mosaics of desert and steppe plant communities due to microrelief variation [Rode, 1971]. Desert habitats with Kochia prostrata and Artemisia pauciflo$r a$ on solonetz soils are associated with microelevations. Microdepressions (up to $0.4 \mathrm{~m}$ depth) provide steppe habitats with forb-grass vegetation (Stipa spp., Festuca valesiaca, Agropyron cristatum, etc.) on dark chestnut and meadow chestnut soils. Microslopes connect these elements and are occupied by typical semidesert vegetation (Agropyron desertorum, Tanacetum achilleifolium, Galatella villosa etc.) on light chestnut soils. Forest stands formed by shelter-belts and small forest communities grow in the territory of the Dzhanybek Station. Hyper-halophytic plant communities occupy salt-marshes on the banks of Lake Elton and small saline rivers discharging therein.

Spiders were collected using pitfall trapping and net sweeping.

In the descriptions, chaetotaxy is given by the following formula: 2.2.1.1, which refers to the number of dorsal spines on tibiae I-IV, respectively. The sequence of leg segments in measurement data is as follows: femur + patella + tibia + metatarsus + tarsus. All measurements are given in $\mathrm{mm}$. Scale lines in figures $=0.1$ $\mathrm{mm}$, unless otherwise indicated. 


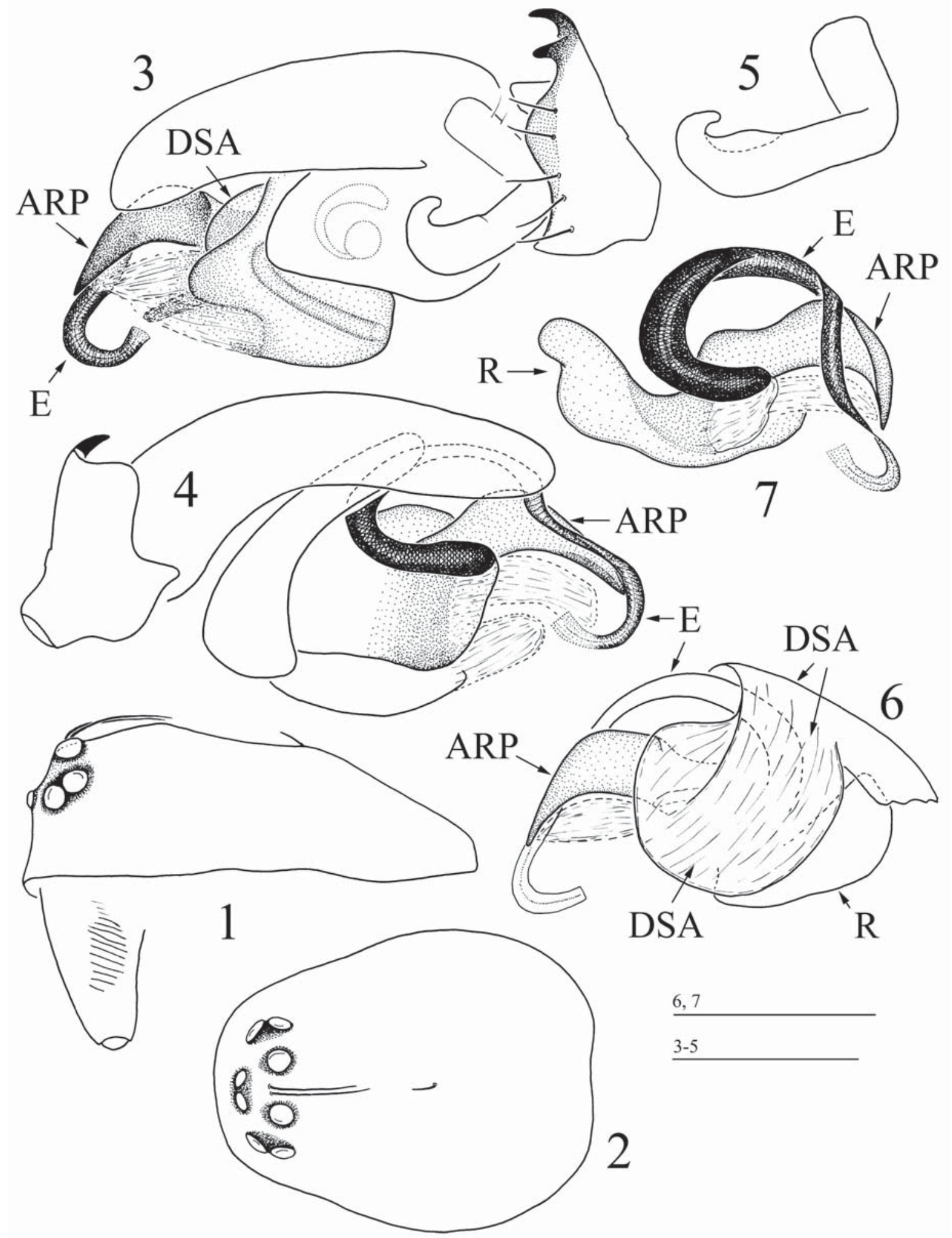

Figs 1-7. Male carapace \& details of palp structure of Trichoncoides striganovae sp.n., paratype. 1, 2 - male carapace, lateral \& dorsal views, respectively; 3,4 - left palp, retro- \& prolateral views, respectively; 5 - paracymbium; 6 - distal suprategular apophysis \& embolic division; 7 - embolic division.

Рис. 1-7. Карапакс и детали пальпы самца Trichoncoides striganovae sp.n., паратип. 1, 2 - карапакс самца, сбоку и сверху, соответственно; 3,4 - левая пальпа, ретро- и пролатерально, соответственно; 5 - парацимбиум; 6 - дистальный супратегулярный апофиз и эмболюсный отдел; 7 - эмболюсный отдел. 


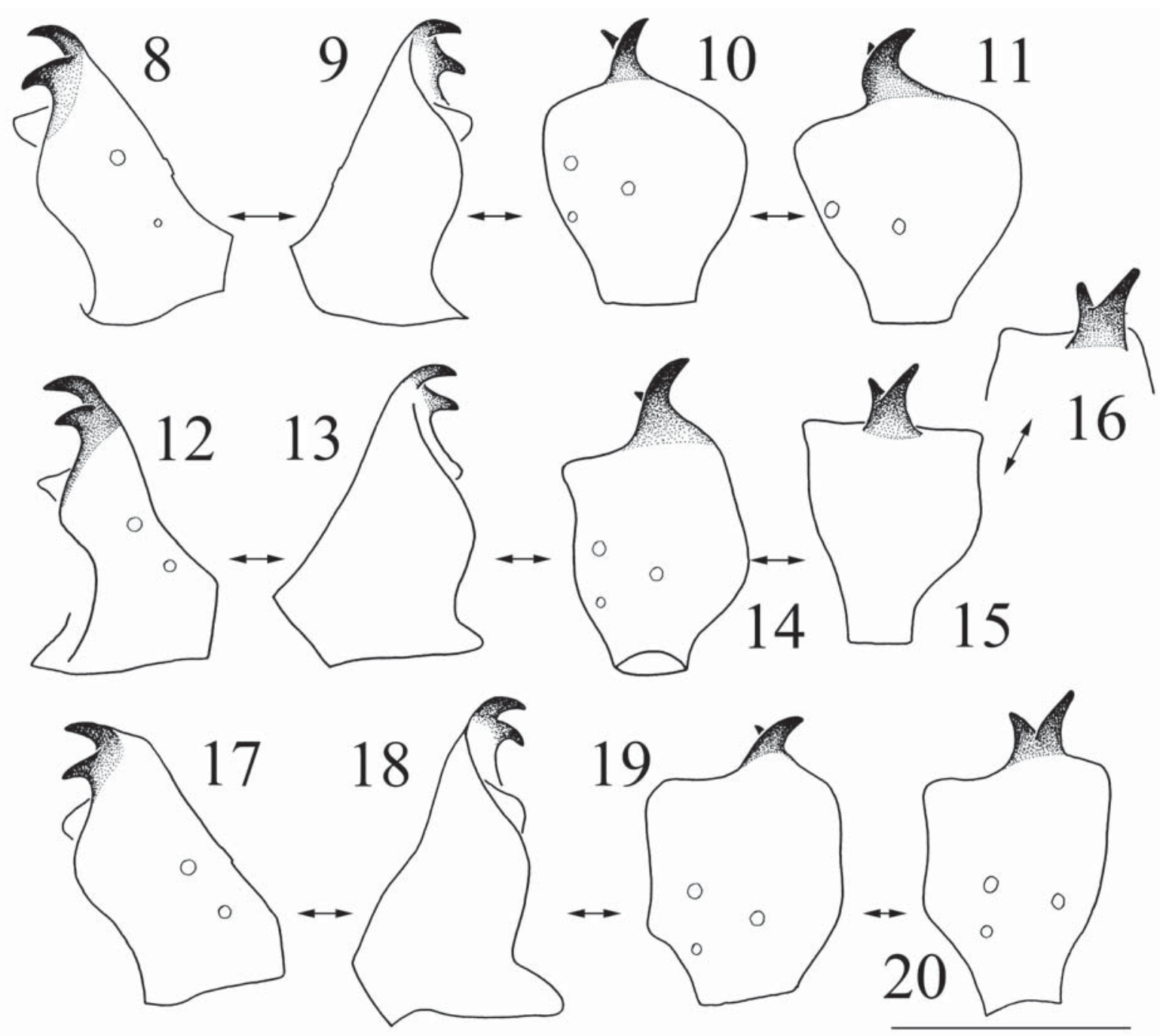

Figs 8-20. Palpal tibia of Trichoncoides striganovae sp.n., holotype (8-11) \& paratypes (12-20). 8, 12, 17 - retrolateral view; 9, 13, 18 - prolateral view; 10, 11, 14-16, 19, 20 - dorsal view; 12-16 - specimen from Dzhanybek, Kazakhstan; 17-20 - specimen from Khara River, Russia (17 - shown in a slightly different aspect than in Figs 8 \& 12).

Рис. 8-20. Голень пальпы самца Trichoncoides striganovae sp.n., голотип (8-11) и паратипы (12-20). 8, 12, 17 — ретролатерально; 9, 13, 18 - пролатерально; 10, 11, 14-16, 19, 20 - вид сверху; 12-16 - экземпляр из Джаныбека, Казахстан; 17-20 — экземпляр c p. Хара, Россия (17 - показан под другим углом, чем на рис. 8 и 12$)$.

The names of the localities are given according to Google Earth.

The following abbreviations are used in the text and figures: ARP — anterior radical process; DSA distal suprategular apophysis; E - embolus; $\mathrm{MHNG}$ Muséum d'histoire naturelle, Geneva, Switzerland; R radix; TmI - the position of the metatarsal trichobothrium; ZMMU - Zoological Museum of the Moscow State University.

Type specimens are shared between the collections of ZMMU and MHNG. Some more samples used here for comparative purposes are also housed in MHNG.

\section{Trichoncoides striganovae sp.n.}

Figs 1-20, 40-42, 46.

2009a Trichoncoides cf. piscator — Piterkina: 341. 2009b Trichoncoides cf. piscator — Piterkina: 339.

2009 Trichoncoides cf. piscator - Piterkina, Mikhailov: 66

2011 Trichoncoides cf. piscator — Piterkina: 100, 102.

MATERIAL: Holotype $1 \sigma^{7}$ (ZMMU), KAZAKHSTAN, West Kazakhstan Area, environs of Dzhanybek (= Zhanibek), Dzhanybek Research Station ( $\left.49^{\circ} 23^{\prime} 52.87^{\prime \prime} \mathrm{N} 46^{\circ} 47^{\prime} 46.31^{\prime \prime} \mathrm{E}\right)$, semi-desert, desert association with Kochia prostrata and Artemisia pauciflora $\left(49^{\circ} 23^{\prime} 39.88^{\prime \prime} \mathrm{N} 46^{\circ} 47^{\prime} 50.04^{\prime \prime} \mathrm{E}\right)$, sweeping, 6.V.2004, leg. T. Piterkina.

Paratypes: $1 \sigma^{7}$ (ZMMU), KAZAKHSTAN, West Kazakhstan Area, environs of Dzhanybek (= Zhanibek), Dzhanybek Research Station $\left(49^{\circ} 23^{\prime} 52.87^{\prime \prime} \mathrm{N} 46^{\circ} 47^{\prime} 46.31^{\prime \prime} \mathrm{E}\right)$, semi-desert, desert association with Kochia prostrata and Artemisia pauciflora $\left(49^{\circ} 23^{\prime}\right.$ $\left.39.88^{\prime \prime} \mathrm{N} 46^{\circ} 47^{\prime} 50.04^{\prime \prime} \mathrm{E}\right)$, pitfall traps, 10-15.V.2004, leg. T. Piterkina; 1 \& (ZMMU), same locality, pitfall traps, 30.IV-5.V.2005, leg. T. Piterkina; $1 \sigma^{\prime}$ (ZMMU), same locality, sweeping, 13.VII.2004, leg. T. Piterkina; 1 (ZMMU), same locality, pitfall traps, 510.V.2005, leg. T. Piterkina; 1 (ZMMU), same locality, steppe association with diverse herbs, sweeping, 23.IV.2004, leg. T. Piterkina; 1 (MHNG), same locality, sweeping, 3.VII.2004, leg. T. 

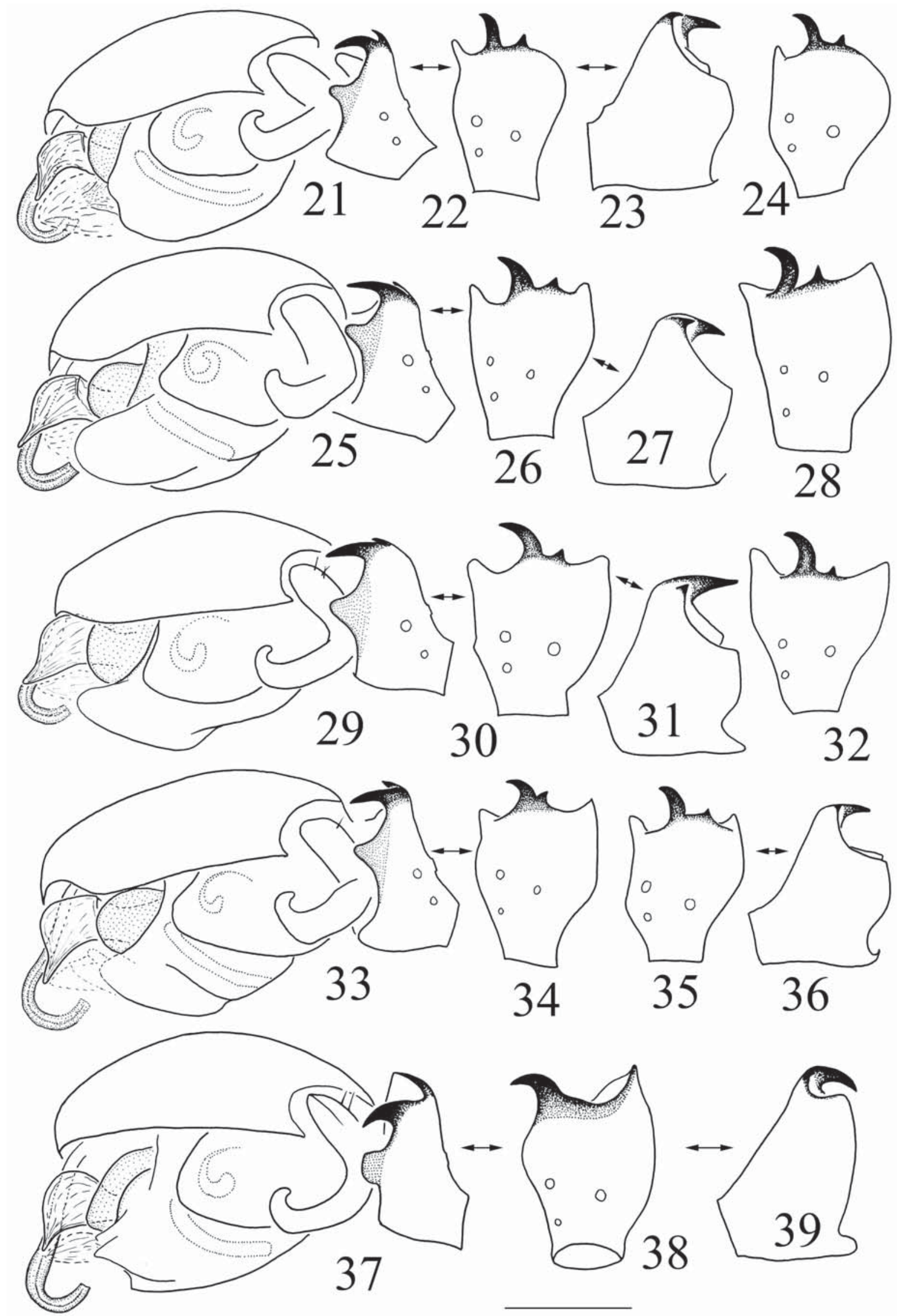
Piterkina; 1 ๆ (MHNG), same locality, sweeping, 12.VII.2004, leg. T. Piterkina; $1 \sigma^{7}$ (ZMMU), RUSSIA, Volgograd Area, environs of Lake Elton, slope of floodplain terraces on right bank of Khara River, $4 \mathrm{~km}$ upstream of river mouth $\left(49^{\circ} 12^{\prime} 54.60^{\prime \prime} \mathrm{N}\right.$ $46^{\circ} 40^{\prime} 1.80^{\prime \prime} \mathrm{E}$ ), semi-desert, grass-forb steppe association, pitfall traps, 10-20.IV.2007, leg. K. Makarov \& A. Matalin; 1 O $^{7}$ (ZMMU), ca $45 \mathrm{~km} \mathrm{NW}$ of Elton Village, upper reaches of Khara River $\left(49^{\circ} 21^{\prime} 58.86^{\prime \prime} \mathrm{N} 46^{\circ} 21^{\prime} 47.40^{\prime \prime} \mathrm{E}\right)$, semi-desert, steppe association with Festuca valesiaca and Agropyron desertorum, pitfall traps, 25.IV-5.V.2011, leg. O. Bukhareva \& A. Bykov.

COMPARATIVE MATERIAL EXAMINED: Trichoncoides piscator (Simon, 1884): 1 (MHNG), KAZAKHSTAN, West Kazakhstan Area, environs of Dzhanybek (= Zhanibek), Dzhanybek Research Station, semi-desert, shelter-belt with Quercus robur $\left(49^{\circ} 23^{\prime} 25.19^{\prime \prime} \mathrm{N} 46^{\circ} 47^{\prime} 37.03^{\prime \prime} \mathrm{E}\right)$, pitfall traps, 20-25.V.2005, leg. T. Piterkina; $1 \overbrace{}^{\top}$ (MHNG), same locality, desert association with Kochia prostrata and Artemisia pauciflora, sweeping, 18.V.2004, leg. T. Piterkina; $1 \sigma^{7}$ (ZMMU), same locality, steppe association with diverse herbs, sweeping, 23.IX.2004, leg. T. Piterkina; 19 (ZMMU), same locality, pitfall traps, 25-30.IX.2004; 2 우 (ZMMU), East Kazakhstan Area, Buchtarminska Reservoir, 10 km S of Slavyanka, 8.V.1998, leg. R. Dudko; 3 ○ $\sigma^{7}$ (ZMMU), RUSSIA, Volgograd Area, environs of Lake Elton, $3 \mathrm{~km}$ upstream of Khara River mouth, floodplain terrace on right river bank $\left(49^{\circ} 12^{\prime} \mathrm{N}\right.$ $\left.46^{\circ} 40^{\prime} \mathrm{E}\right)$, salina with Salicornia prostrata, pitfall traps, 2 11.IV.2007, leg. K. Makarov \& A. Matalin; 4 O $^{7} \sigma^{\top}, 1$ ㅇ (ZMMU), same locality, pitfall traps, 10-20.IV.2007, leg. K. Makarov \& A Matalin; $1 \sigma^{7}$ (ZMMU), Lake Elton, salt-marsh on bed-rock coast near Khara River mouth $\left(49^{\circ} 10^{\prime} 3.00^{\prime \prime} \mathrm{N} 46^{\circ} 51^{\prime} 39.00^{\prime \prime} \mathrm{E}\right)$, pitfall

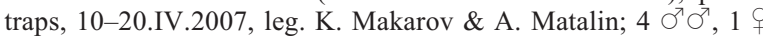
(ZMMU), ISRAEL, $10 \mathrm{~km}$ SSW of Beit-Shemesh, Adullam Nature Reserve, 300-400 m, pitfall traps, 10.III.2008, leg. O. Skutetsky; 3 $\sigma^{\top} \sigma^{7}, 3$ 우 (ZMMU), IRAN, Tehran, Firuz Kun $\left(35^{\circ} 45^{\prime} \mathrm{N}, 52^{\circ} 46^{\prime} \mathrm{E}\right)$, 23.VII.1973, leg. A. Senglet; 1 o (ZMMU), AZERBAIJAN, Baku (=Baki), 9.VI.1985, leg. P. Dunin; 1 ○' (ZMMU), Azerbaijan, Caucasus, Saatli Distr., Djafarkhan, 0 m a.s.1., 24.VIII.1982, leg. P. Dunin; 1 (ZMMU), Zakataly (= Zaqatala), floodplain of Talachai River, 550-560 m a.s.1., 7.VI.1986, leg. K. Mikhailov; 1 (ZMMU), Shamakhi (= Samaxi) Distr., Pirkuli (= Pirqulu), 1200-1300 m a.s.1., sweeping, 26.V.1984, leg. D. Logunov; $2 \sigma^{7} \sigma^{7}$ (ZMMU), TURKMENISTAN, Kopetdagh Mts., bank of Sumbar (= Sari-su) River, 8-13.V.1983, leg. S. Zabelin.

DIAGNOSIS: The new species is similar to $T$. piscator (Simon, 1884), but differs well by the absence of a small retrolateral outgrowth on the palpal tibia, by a peculiar modification of the apicodorsal tibial teethshaped apophyses, by a narrower and more protruded anterior radical process in male. The female is particular in a darkened wedge-shaped stem of the median plate and in spherical receptacles surrounded by the seminal ducts.

NAME: The new species honours Professor Bella R. Striganova, a renowned scientist, one of the leaders in soil zoology and ecology in Russia.

DESCRIPTION: Male (holotype). Total length, 1.38. Carapace pale brown, unmodified, with an indistinct, grey, polygonal, median spot and a narrow dark margin, 0.70 (0.63-0.70 in paratypes) long, 0.53 wide.
Carapace bearing one long spine (some paratypes with two ones attached between posterior median eyes, directed backwards and bent down to carapace surface (as shown in Figs 1 \& 2). Chelicerae, 0.23 long, unmodified, stridulatory furrows distinct. Legs brownish yellow. Leg I, 1.89 long $(0.53+0.20+0.45+0.40+$ $0.31)$, IV, 1.98 long $(0.55+0.18+0.50+0.45+0.30)$. Chaetotaxy: 2.2.1.1, spines weak, their length about $1-$ 1.5 diameter of segment. TmI, $0.46(0.43-0.46$ in paratypes). Metatarsus IV without trichobothrium. Palp (as shown in Figs 3-20): Palpal tibia apicodorsally with two claw-shaped teeth situated on same base; lateral edges evenly convex, without outgrowth (shown in Fig. 3). Paracymbium simple, L-shaped. Frontal part of tegulum membraneous, poorly visible. Distal suprategular apophysis hypertrophied: very wide, expanded, transparent partly, as a thin tissue enveloping radical part of embolic division. Anterior radical process relatively long and narrow, tapering smoothly to a sharp tip. Embolus long and curved, distal part describing semicircle. Abdomen 0.75 long, 0.50 wide, grey.

Female. Total length 1.75. Carapace $0.83(0.65-$ 0.83 ) long, 0.55 wide, similar in shape to male, but without special spines in head area. Chelicerae 0.35 long. Leg I, 1.99 long $(0.55+0.20+0.48+0.43+$ $0.33)$, IV , 2.04 long $(0.60+0.18+0.53+0.45+0.28)$. TmI $0.41(0.41-0.44)$. Abdomen 1.15 long, 0.70 wide. Epigyne (as shown in Figs 40-42): Base of median plate covered with a black, small, rounded visor. Stem of median plate brown to black, wedge-shaped: narrowed down until or almost until expanded part of median plate. Receptacles spherical, seminal ducts in its middle and distal parts much wider than their proximal parts, fully surrounded by seminal ducts. Body and leg coloration, as well as chaetotaxy, as in male.

VARIABILITY: Variation in size as shown above in Description. Carapace shape in males stable, maximum two long peculiar spines on male head; if absent or one, then most likely broken off. Shape of epigyne, male palpal tibia, distal suprategular apophysis and anterior radical process more or less stable, with only minor variations. Carapace coloration from yellow to brown in both sexes, abdomen from grey to white.

TAXONOMIC REMARKS: T. striganovae sp.n. is very similar to $T$. piscator, but differs well by the absence of a small retrolateral outgrowth on the palpal tibia (Figs 3, 8, 12, 17 cf. Figs 21, 25, 29, 33, 37), by the shape of apicodorsal, tibial, tooth-like apophyses situated on the same base (Figs 8-20 cf. Figs 21-39). The anterior radical process is narrower and longer

Figs 21-39. Details of palp structure of Trichoncoides piscator (Simon, 1884). 21, 25, 29, 33, 37 — left palp, retrolateral view; 22-24, 26-28, 30-32, 34-36, 38, 39 — palpal tibia; 22, 24, 26, 28, 30, 32, 34, 35, 38 - dorsal view; 23, 27, 31, 36, 39- prolateral view; 21-23 specimen from Dzhanybek, Kazakhstan; 24 - specimen from near Lake Elton, Russia; 25-28 — specimens from Firuz Kun, Iran; 29 -32 specimens from Djafarkhan, Azerbaijan; 33-36 — specimens from Sumbar, Turkmenistan; 37-39 — specimens from Adullam Nature Reserve, Israel. Arrows indicate which details belong to the same specimen.

Рис. 21-39. Детали пальпы самца Trichoncoides piscator (Simon, 1884). 21, 25, 29, 33, 37 - левая пальпа, ретролатерально; 22-24, 26-28, 30-32, 34-36, 38, 39 - голень пальпы; 22, 24, 26, 28, 30, 32, 34, 35, 38 - вид сверху; 23, 27, 31, 36, 39 пролатерально; 21-23 - экземпляр из Джаныбека, Казахстан; 24 - экземпляр с оз. Эльтон, Россия; 25-28 - экземпляры из Firuz Kun, Иран; 29-32 - экземпляры из Джафархана, Азербайджан; 33- 36 - экземпляры из Сумбар, Туркменистан; 37-39 экземпляры из заповедника Adullam, Израиль. Стрелки указывают на один и тот же экземпляр. 

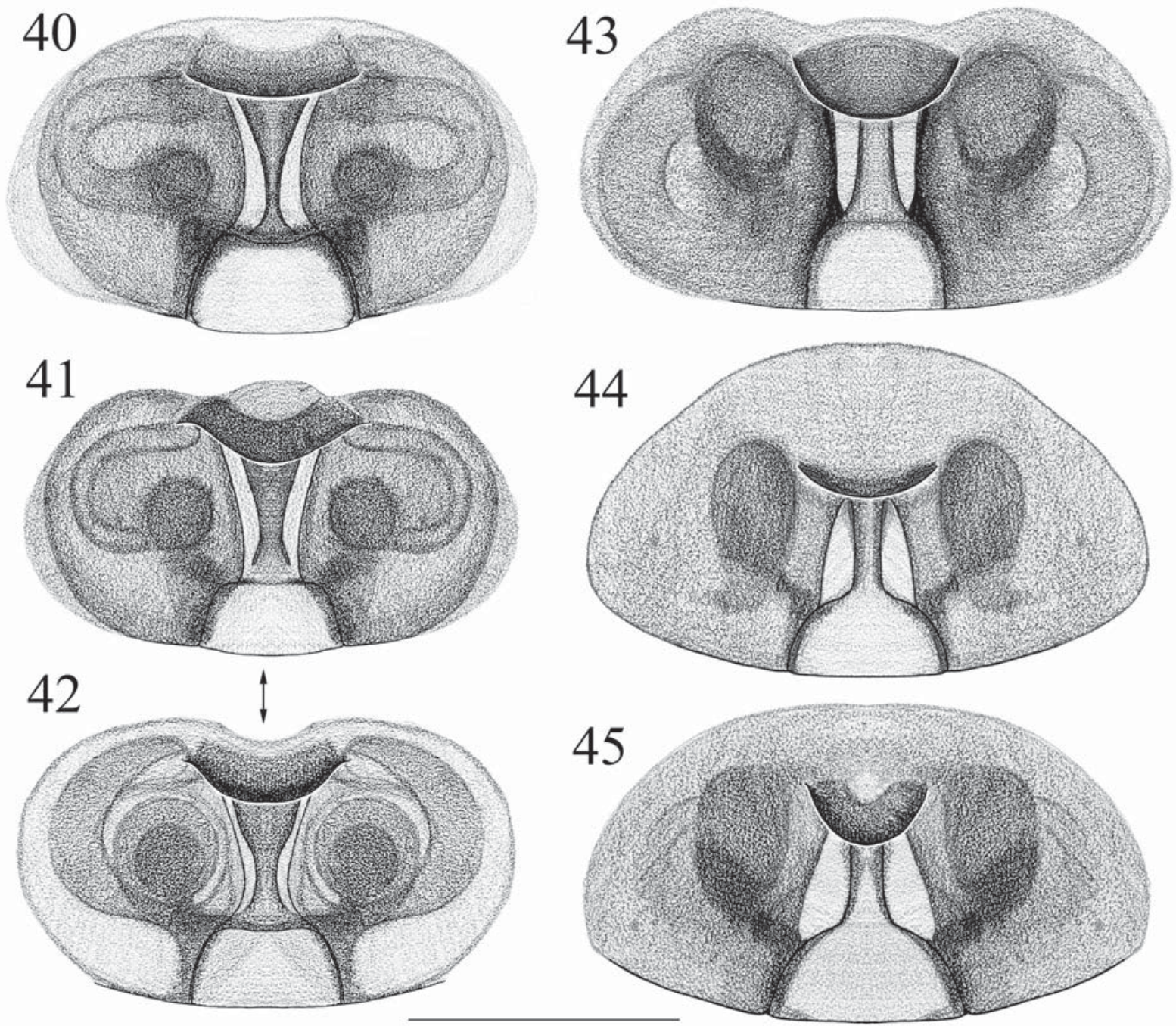

Figs 40-45. Epigynes of Trichoncoides striganovae sp.n., paratypes (40-42) \& T. piscator (Simon, 1884) (43-45). 40-42, 44, $45-$ specimens from Dzhanybek, Kazakhstan; 43 - specimen from Adullam Nature Reserve, Israel; 42 - epigyne same as shown in Fig. 41, but slightly cleared with $\mathrm{KOH}$. Arrows indicate which details belong to the same specimen.

Pис. 40-45. Эпигины Trichoncoides striganovae sp.n., паратипы (40-42) и T. piscator (Simon, 1884) (43-45). 40-42, 44, 45 экземпляры из Джаныбека, Казахстан; 43 - экземпляр из заповедника Adullam, Израиль; 42 - эпигина та же, что и на Рис. 41, но слегка просветлённая едким кали. Стрелки указывают на один и тот же экземпляр.

(Fig. 3 cf. Figs 21, 25, 29, 33, 37). The female can easily be distinguished by a darkened wedge-shaped stem of the median plate, by partly transparent, nearly loop-shaped seminal ducts on both sides of the median plate, as well as by spherical receptacles fully surrounded by the seminal ducts (Figs 40-42, $46 \mathrm{cf}$. Figs $43-45,47,48)$. The illustrations of the epigyne provided by Denis [1950: 15; 1966: 2] for T. pilosus Denis, 1950 , the second congener known only from the female, are insufficiently clear to compare to that of $T$. striganovae sp.n., but both species can easily be separated by the shape of the carapace: regularly convex in $T$. pilosus versus complex in profile and similar to that of the male in T. striganovae sp.n. (as shown in Figs 1,
2). The epigyne of $T$. striganovae sp.n. resembles that illustrated by Miller [1966, fig. 4] for Paratrichoncus vejdovskyi (Miller, 1939) [= Trichoncoides piscator sensu Georgescu, 1970] from Brno, Czech Republic, notably the shape of the stem of the epigynal median plate, yet the figure of the vulva [Miller, 1966, fig. 5] really shows differences from $T$. striganovae sp.n.

NATURAL HISTORY: The species seems to be quite rare. Only ten specimens $\left(6 \sigma^{7} \sigma^{7}, 4\right.$ qo) have been obtained over 5 years of sampling. Females occur in April-May, males from April till July. Inhabits steppe and desert associations. In both of these habitats, $T$. striganovae sp.n. occurs together with the very similar species, $T$. piscator. 


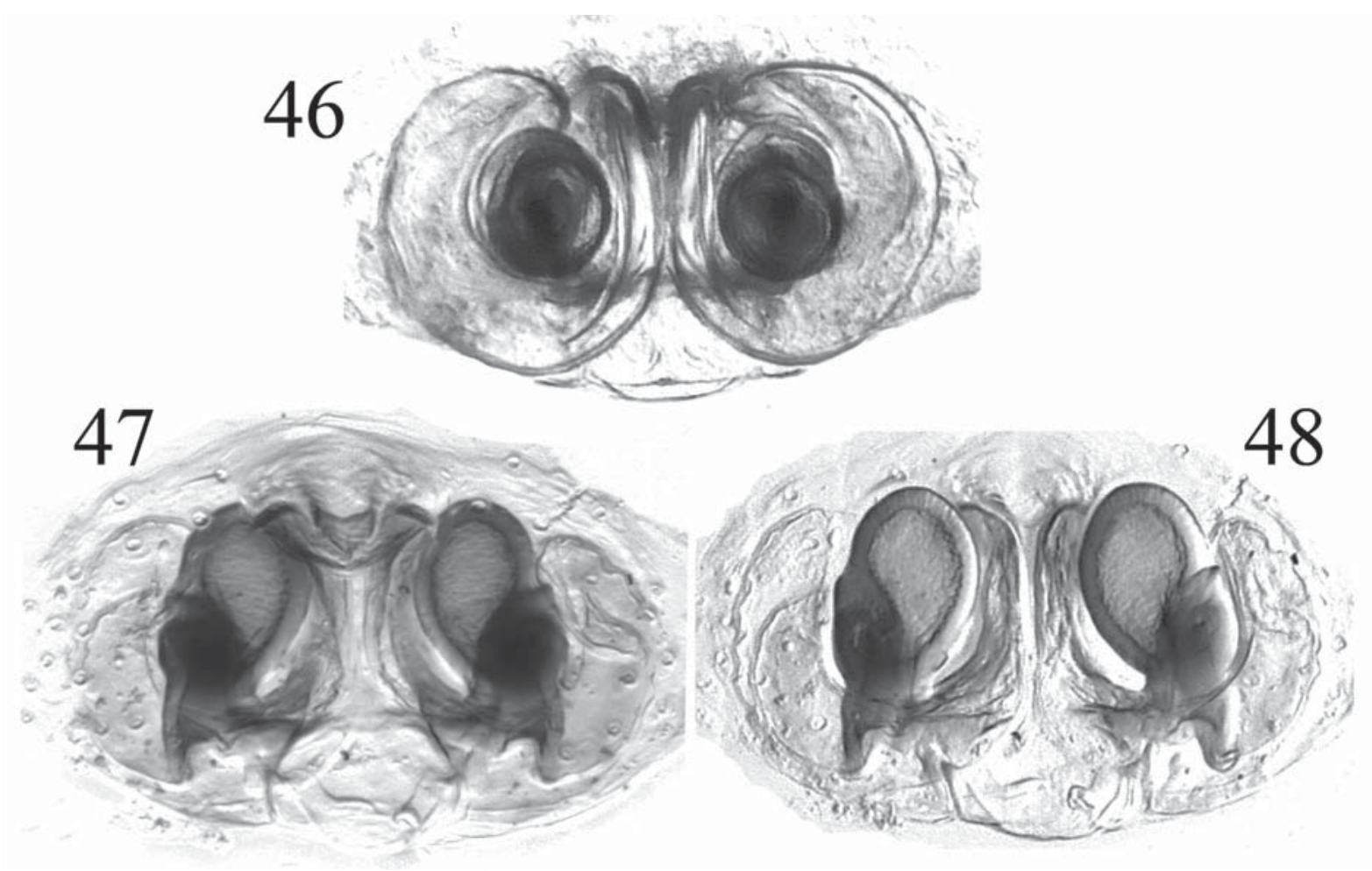

Figs 46-48. Vulvae of Trichoncoides striganovae sp.n., paratype from Dzhanybek, Kazakhstan (46) \& T. piscator (Simon, 1884), specimen from Adullam Nature Reserve, Israel $(47,48) .46,48$ - dorsal view; 47 — ventral view.

Рис. 46-48. Эндогины Trichoncoides striganovae sp.n., паратип из Джаныбека, Казахстан (46) и T. piscator (Simon, 1884), экземпляр из заповедника Adullam, Израиль $(47,48)$. 46, 48 - вид сверху; 47 - вид снизу.

DISTRIBUTION: Currently known from a small area in the southeastern part of the Russian Plain, Russia and Western Kazakhstan.

NOTE: The genus Trichoncoides Denis, 1950 was established for $T$. pilosus, based on a single female from Camargue, France [Denis, 1950]. Because the holotype was poorly depicted, while a conspecific male remains unknown, we can hardly be sure that both $T$. piscator and T. striganovae sp.n. are actually congeneric with $T$. pilosus, the type species.

Throughout its Ancient Mediterranean distribution, T. piscator shows considerable variability, mostly in size, position and arrangement of the apicodorsal toothlike apophyses on the male palpal tibia (see Figs 2139). However, the other genital structures such as distal suprategular apophysis, embolus, anterior radical process, as well as the arrangement and shape of the receptacles and seminal ducts seem to be rather stable. Thus, European, North African and Levantine representatives of the genus have two widely separated tooth-like apophyses, the prolateral one often being absent (see Fig. 38 \& Bosmans, 2007, fig. 160). In contrast, specimens from the eastern part of the range show these apophyses more strongly drawn together, even up to being in contact at their bases (see Fig. 34). Currently no-one can be sure if we face variability in male palpal structure within a single species, or else T. piscator is a composite taxon to be split in the future.

ACKNOWLEDGEMENTS. The authors are indebted to Mamai Sapanov and Marina Sizemskaya (Moscow, Russia) for giving a chance to work on the Dzhanybek Research Station. We are deeply obliged to the collectors - Kirill Makarov and Andrei Matalin, as well as to Olga Bukhareva and Alexander Bykov (Moscow, Russia) for providing material. We also wish to thank Kirill Mikhailov for the opportunity to work on the spider collections of the Zoological Museum of the Moscow State University, Moscow, Russia. Sergei Golovatch (Moscow, Russia) kindly checked the English of an advanced draft.

The study was partly supported by the Russian Foundation for Basic Research (\# 11-04-00941), the President Programme for the Support of Leading Scientific Schools (3708.2012.4) and the Programme "Biosphere Origin and Evolution" of the Russian Academy of Sciences.

\section{References}

Bosmans R. 2007. Contribution to the knowledge of the Linyphiidae of the Maghreb. Part XII. Miscellaneous erigonine genera and additional records (Araneae: Linyphiidae: Erigoninae) // Bull. Annls Soc. r. belge Ent. T.143. P.117-163. 
Denis J. 1950. Araignées de France. III. Araignées de Camargue // Revue fr. Ent. T.17. P.62-78.

Denis J. 1966. Notes sur les érigonides (Araignées). XXXIV. Le genre Trichoncoides Denis // Bull. Mus. natn. Hist. nat. Paris. T.38. P.233-237.

Georgescu M. 1970. Données systématiques sur le genre Trichoncoides Denis (Araneae, Micryphantidae)// Reichenbachia. Bd.13. S.211-218

Gnelitsa V.A. 2008. Pelecopsis steppensis sp.n. (Aranei: Linyphiidae) from southern Ukraine // Arthropoda Selecta. Vol.16. No.2. P.137-141.

Gnelitsa V.A., Ponomarev A.V. 2010. A new Centromerus Dahl, 1886 (Aranei: Linyphiidae: Micronetinae) from south of the Russian plain // Arthropoda Selecta. Vol.19. No.4. P.265-268.

Milkov F.N., Gvozdetsky N.A. 1986. [Physiography of the USSR] Moskva: Vysshaya shkola Publ. 512 p. [in Russian].

Miller F. 1966. Einige neue oder unvollkommen bekannte Zwergspinnen (Micryphantidae) aus der Tschechoslowakei (Araneidea) // Acta ent. bohemoslavaca. Bd.63. S.149-164.

Piterkina T.V. 2009a. Spiders (Arachnida, Araneae) of the Dzhanybek Research Station, West Kazakhstan: a local fauna in a biogeographical aspect // Golovatch S.I., Makarova O.L, Babenko A.B. \& Penev L.D. (eds). Species and communities in extreme environments Sofia \& Moscow: Pensoft Publishers \& KMK Scientific Press. P.335-356.

Piterkina T.V. 2009b. [Spiders (Arachnida, Araneae) of the Dzhanybek Research Station, West Kazakhstan: a local fauna in a biogeographical aspect] // Babenko A.B., Matveyeva N.V., Makarova O.L. \& Golovatch S.I. (eds). Vidy i soobschestva v ekstremal'nikh usloviyakh. Moscow \& Sofia: KMK Scientific Press \& Pensoft Publishers. P.335-352 [in Russian]
Piterkina T.V. 2011. Spatial and temporal structure of the spider community in the clay semi-desert of western Kazakhstan // Arachnologische Mitteilungen. Bd.40. S.94-104.

Piterkina T.V., Mikhailov K.G. 2009. [Annotated check-list of spiders (Aranei) of Dzhanybek Station] // Tishkov A.A. (ed.). Zhivotnyie glinistoi polupustyni Zavolzhya (konspekty faun i ekologicheskiye kharakteristiki) Moscow: KMK Scientific Press. P.62-88 [in Russian].

Rode A.A. 1971. [Natural conditions and experimental plantations of the Dzhanybek Station] // Rode A.A. (ed.). Zhivotniye iskusstvennikh lesnykh nasazhdenii $\mathrm{v}$ glinistoi polupustyne. Nauka, Moscow. P.5-12 [in Russian].

Tanasevitch A.V., Piterkina T.V. 2007. Four new species of the spider family Linyphiidae (Aranei) from clay semi-desert of Western Kazakhstan // Arthropoda Selecta. Vol.16. No.1. P.23-28.

Tanasevitch A.V. 1986. New and little-known species of Lepthyphantes Menge 1866 from the Soviet Union (Arachnida: Araneae: Linyphiidae) // Senckenbergiana Biol. Bd.67. H.1/3. S.137-172.

Tanasevitch A.V. 1987. A new genus of spiders of the subfamily Erigoninae (Aranei, Linyphiidae) from Western Kazakhstan // Biol. Nauki. No.11. P.72-75 [in Russian, with English summary].

Tanasevitch A.V. 1993. A new species of Trachelocamptus Simon from Western Kazakhstan (Arachnida: Araneae: Linyphiidae: Micronetinae) // Reichenbachia. Bd.30. Nr.2. S.5-6.

Tanasevitch A.V. 2004. Two new erigonine spiders from the steppe of the East European Plain (Aranei: Linyphiidae: Erigoninae) // Arthropoda Selecta. Vol.13. No.1-2. P.63-67. 